\title{
Chronic Kidney Disease - Chronic Liver Disease. An Immunologic Cross-talk
}

\author{
GH. GLUHOVSCHI ${ }^{1}$, LIGIA PETRICA ${ }^{2}$, I. SPOREA ${ }^{3}$, R. TIMAR ${ }^{4}$, MANUELA CURESCU $^{4}$, \\ SILVIA VELCIOV ${ }^{2}$, CRISTINA GLUHOVSCHI \\ ${ }^{1}$ Romanian Academy of Medical Sciences, Emergency Clinical County Hospital, Timişoara , Romania \\ 2“V. Babeş" University of Medicine and Pharmacy, Emergency Clinical County Hospital, Timişoara, Romania \\ ${ }^{3}$ Romanian Academy of Medical Sciences, "V. Babeş" University of Medicine and Pharmacy, \\ Emergency Clinical County Hospital, Timişoara, Romania \\ 4،V. Babeş" University of Medicine and Pharmacy, Clinic of Infectious Diseases, Timişoara, Romania
}

The relationship between the kidney and other organs is notable. The bestknown is the relation with the cardiovascular system. Relationships with other organs are less studied, although their involvement sometimes dominates the clinical picture and the outcome of disease.

The paper analyzes the kidney-liver relationship, namely chronic kidney disease and chronic liver disease from an immune viewpoint. The immune system operates as a unitary whole. There is an interdependence between the immune system of the liver, considered a lymphoid organ, and the kidney, whose participation in immune processes is well-known.

The most important chronic liver diseases are viral hepatitis B and C. Infection with these viruses can lead to renal involvement, producing mainly glomerular disease.

At the same time, secondary glomerulonephritis can cause an unfavorable outcome of the primary disease.

The relationship between chronic liver disease and chronic kidney disease during chronic B and $\mathrm{C}$ hepatitis occurs via circulating immune complexes or complexes formed in situ. Cell-mediated immunity is also involved.

The antiviral treatment of $\mathrm{B}$ and $\mathrm{C}$ hepatitis is also aimed at secondary glomerular disease.

The participation of immune mechanisms raises the question of administering immunomodulating medication, a type of medication that influences viral replication - this is why it is associated with antiviral medication.

Other two chronic liver diseases, namely liver cirrhosis, in which the main mechanism is a toxic one, and non-alcoholic steatohepatitis can produce via immune mechanisms glomerular involvement.

In its turn, chronic kidney disease in advanced stages causes lipid metabolism disturbances with hypertriglyceridemia, which can influence fatty loading of the liver in the above-mentioned liver diseases.

One can speak about a cross-talk between the liver and the kidney, in which immune mechanisms play an important role.

Key words: chronic kidney desease, chronic liver desease, immune complexes.

Both the kidneys and the liver are unanimously known as organs essential for ensuring the homeostasis of the body. In fact, the body operates as a unitary whole, having functional relations among different organs.

It is easily explainable why external aggression can impair both organs directly or indirectly.

The most relevant example is represented by viral infection with the hepatitis viruses $\mathrm{B}$ and $\mathrm{C}$, real pandemics that affect a large segment of the population and require costly therapeutic and prophylactic measures.

Although these viruses do not have a special tropism for the kidneys, the kidneys can be involved as well. This occurs as a consequence of the long-term presence of the viruses in the body, the liver being the most important depository of both hepatitis $\mathrm{B}$ and $\mathrm{C}$ viruses.

The protective mechanisms against these viruses are based on the strong immune system of the liver, involving the whole immune system of the body of which it is a constitutive part. The intervention of immune mechanisms will lead to the formation of antibodies which will form with the HBV and HCV viruses immune complexes containing immunoglobulins and viral antigens.

The kidney is the main organ in which elimination of catabolism products takes place, being at the same time equipped with immune defense mechanisms. The presence of viral antigens 
and of immune complexes will have a deleterious effect on the kidneys, with ensuing inflammatory processes leading to glomerulonephritis that can progress to chronic kidney disease, while hepatic inflammatory processes related to hepatitis viruses $\mathrm{B}$ and $\mathrm{C}$ can cause chronic liver disease.

Thus, we are confronted with an association of chronic kidney disease (CKD) with chronic liver disease (CLD). Immune pathogenic links between them produce a real cross-talk.

The presence of an immune relation between the two organs is not limited to viral infection diseases. It can also occur during metabolic diseases and disorders related to high consumption of toxics, such as alcohol.

\section{CHRONIC HEPATITIS B VIRUS-ASSOCIATED GLOMERULONEPHRITIS}

HBV hepatitis is a disease which frequently has a chronic evolution. The number of people chronically infected with HBV who become virus carriers is estimated at about $350,000-400,000$ persons [1].

HBV is a virus with hepatic tropism, but it is not cytopathic per se. According to Trepo et al., liver damage and viral control would be related to virus replication and host immune response [2]. The initial acute infection can turn chronic, becoming HBV chronic hepatitis. This can progress to cirrhosis or even to liver cancer.

The hepatic localization causes liver damage while accompanying immune phenomena are aimed at eliminating or limiting the action of HBV.

At liver level important mechanisms of cell immunity that involve mainly $\mathrm{T}$ cells are operational.

In HBV chronic hepatitis, the liver is not able to eliminate $\mathrm{HBV}$, and it remains an important virus depository. Antigens derived from the HBV virus can however be eliminated from this level.

The presence in the circulation of the main antigens $\mathrm{HBs}, \mathrm{HBc}$, and $\mathrm{HBe}$ is identified by laboratory tests. These can also detect viremia, that is HBV-DNA.

In the circulation antibodies against HBV and antigens derived from it can be found.

There are also situations in which antigens can be present in the circulation without manifesting themselves as clinical and biological hepatic lesions.

In fact, present-day treatments are considered to be able to stop the evolution of the disease without ensuring total virus clearance.
Extrahepatic manifestations can also be found during HCV chronic hepatitis. One of the extrahepatic manifestations is renal involvement such as glomerulonephritis.

The relation between liver and kidney involvement during $\mathrm{HCV}$ chronic hepatitis can be carried out in different ways:

- by means of circulating immune complexes

- by means of immune complexes formed in situ

- by means of virus particles filtered at glomerular level and taken up at tubular level by pinocytosis processes.

\section{RENAL INVOLVEMENT BY CIRCULATING IMMUNE COMPLEXES}

The elimination of viral antigens into the circulation can lead to the production of specific antibodies. These antibodies, together with HBV antigens, can form circulating immune complexes. Thus, immune complexes can contain immunoglobulins and $\mathrm{HBV}$ antigens: $\mathrm{HBs}, \mathrm{HBc}$ or $\mathrm{HBe}$. For example, Liu et al. identified in HBV hepatitis both the $\mathrm{HBe}$ antigen and antibodies against this antigen [3].

Circulating immune complexes containing HBV antigens and the corresponding antibodies can be deposited at kidney level triggering glomerular inflammatory processes with ensuing glomerulonephritis that can become chronic.

Ventkataseshan et al. detected in renal deposits of patients with hepatitis B virus-associated glomerulonephritis glomerular deposits made of two or more immunoglobulins, to which complement deposits can be associated $\left(\mathrm{C}_{3}, \mathrm{C}_{4}, \mathrm{C}_{\mathrm{1q}}\right)$ [4].

Very rarely, deposits of HBV antigens at tubular level were also noticed ([4]. Zhang et al. found in some patients presenting $\mathrm{HBV}$ antigenemia deposits of HBV antigens. These deposits can be associated with deposits of immunoglobulins and complement.

Zhang et al. also reported the presence of $\mathrm{HBV}$ antigens such as $\mathrm{HBcAg}, \mathrm{HBeAg}$, or $\mathrm{HBsAg}$ in the kidneys, although they were absent in the blood [5].

The presence of HBV antigens in the kidneys represents a proof of renal involvement during hepatitis. At present, its detection occurs only in specialized lab services.

Another way in which immune complexes can appear in the kidneys in HBV hepatitis is represented by the in situ formation of immune complexes. 
Circulating HBV antigens are deposited within glomerular structures. The antibodies react with them at this level. The formation of immune complexes in situ is incriminated in membranous nephropathy associated with HBV antigens.

The third mechanism by which HBV antigens can reach the kidneys is represented by the glomerular filtration of the virus and its uptake by pinocytosis.

Cell-mediated immunity also plays a role in the pathogenesis of HBV-associated nephropathy. Thus, a deficiency of cell immune responses against $\mathrm{HBcAg}$ was found in membranous nephropathy [6].

According to Peng et al., T reg cells suppress antigen specific or nonspecific $\mathrm{T}$ cells responses. They could facilitate long-term persistence of the virus in the body [7].

$\mathrm{HBV}$, by its antigenic components, is able to induce molecular mechanisms that allow immune escape [1].

HBV mutations, like those of the $\mathrm{S}$ gene [8] or HBs X gene [9], could also play a role.

The kidney could be a depository where the virus is multiplied. The expression of the HBV genome was identified at both glomerular and tubular level. Research studies detected the presence of HBV-DNA in the glomeruli and tubuli which allows virus replication [10].

The main forms of manifestation of HBV hepatitis are represented by membranous nephropathy, most frequently with sub-epithelial deposits of immune complexes, by IgA nephropathy, and by membranoproliferative glomerulonephritis. In IgA nephropathy deposits of IgA can be found, sometimes associated with IgG deposits and viral antigens.

Membranoproliferative glomerulonephritis occurs more rarely but it has a more severe outcome and can be associated with the presence of cryoglobulins.

HBV-associated glomerular diseases in which the presence of immune complexes was not identified are rare: Minimal change disease (MCD) and focal and segmental glomerulosclerosis (FSGS), the latter being discussed as a sequel of liver cirrhosis.

HBV-associated periarteritis nodosa represents a vasculitis with renal involvement often associated with HBV; there are however cases of this type of vasculitis when the virus is absent.

\section{TREATMENT OF HBV HEPATITIS}

Antiviral therapy is the first-line therapy in renal involvement. Patients with HBV hepatitis were found to be deficient in producing interferon alpha (INF alpha), which diminishes antiviral effects. Consequently, treatment with INF alpha, under the form of pegylated interferon, was introduced in HBV therapy. INF alpha is associated with lamivudine. Other therapeutical options are analogs: entecavir or tenofovir. In cases of resistance, other antivirals such as adefovir can be administered.

Rapidly progressive glomerulonephritis associated with HBV hepatitis requires immunomodulating therapy with steroids and cyclophosphamide.

As these can facilitate viral replication, they are associated with antiviral treatment and they are monitored by measurement of serum HBV DNA.

HBV-associated periarteritis nodosa requires, depending on severity, antiviral therapy which can be associated with steroids and immunosuppressants, sometimes supplemented by plasma exchange.

At present, much attention is given to vaccination, which could produce a specific response of $\mathrm{T}$ cells.

According to Liu et al., vaccination is also efficient for reducing the incidence of membranous nephropathy associated HBV infection [3].

\section{CHRONIC VIRAL HEPATITIS C AND RENAL INVOLVEMENT}

HCV hepatitis is caused by HCV which locates to the liver, where it triggers an inflamematory process with slow and often chronic evolution.

$\mathrm{HCV}$ hepatitis is widely spread throughout the world. It is estimated that at present more than 170,000 persons are infected with HCV. They initially present acute hepatitis, $55-85 \%$ of them having chronic evolution.

Patients with $\mathrm{HCV}$ hepatitis can progress to cirrhosis and even liver cancer. Some individuals are carriers of either the $\mathrm{HCV}$ virus or of antibodies against $\mathrm{HCV}$, without presenting clinical symptoms of liver involvement.

HCV hepatitis can present extra-hepatic manifestations. One of these is glomerulonephritis secondary to this infection. Given the high number of individuals infected with $\mathrm{HCV}$ one can estimate that patients with $\mathrm{HCV}$ glomerulonephritis could be more numerous.

Research studies on the incidence of glomerular involvement in persons with HCV conducted by El-Seraq reported a higher rate of membranoproliferative glomerulonephritis in $\mathrm{HCV}$ patients than in controls [11]. 
Other authors, such as Moe, consider that one cannot affirm that HCV hepatitis is associated with increased risk of developing CKD [12].

A meta-analysis conducted by Fabrizi et al. found higher incidence of proteinuria in $\mathrm{HCV}$ positive patients than in the control group, which could argue in favor, at least partly, for an increased frequency of glomerulopathy [13].

\section{PATHOGENESIS OF GLOMERULAR INVOLVEMENT}

$\mathrm{HCV}$ is a hepatotropic virus. Experimental studies showed that HCV is not cytopathic per se. The lesions induced by $\mathrm{HCV}$ are related to the inflammatory phenomena they trigger. As a consequence, liver damage ensues, associated with intrahepatic inflammatory infiltrates.

$\mathrm{HCV}$ infection has initially an acute phase. In many situations, the immune system is able to lead to eradication of the virus. In other patients, the immune system is not capable to eliminate the virus. It remains in the body and liver disease becomes chronic.

The persistence of the virus is due to a weak response of the immune system and to a great variability of the virus that causes antibodies to be inefficient. At the same time, mechanisms of molecular mimicry play an important role in producing $\mathrm{HCV}$ hepatitis.

The hepatic immune processes involve liver cells with immune properties such as Kupffer cells and, to a lesser extent, stellate cells. It is common knowledge that the liver is equipped with an immune system represented mainly by Kupffer cells. They are estimated to represent a quarter of the total number of cells the liver is made of. At the same time, T cells, B cells, dendritic cells, neutronphils, NK cells, NKT cells that infiltrate the liver also participate.

In fact, the activation of the immune system is the main factor that intervenes in pathogenic processes at liver level. The $\mathrm{T}$ cell response plays an important role. Cytotoxic $\mathrm{T}$ cells are predominantly involved in the production of HCV-related liver injury.

In recent years an immune protective role against $\mathrm{HCV}$ is attributed to another group of $\mathrm{T}$ cells that achieve "protective immunity": $\mathrm{T}$ regulatory cells/T reg cells. They have an anti- inflammatory role diminishing immune aggressiveness in HCV chronic hepatitis.
In case the immune system is not able to eliminate the virus, it persists in the body and can multiply.

$\mathrm{HCV}$ antigens can be present in the circulation, leading to production of anti-HCV antibodies. Together, they can form immune complexes. Some of these immune complexes precipitate in the cold, being defined as cryoglobulins. The structure of cryoglobulins can include polyclonal IgG (polyclonal immunoglobulins G) that combine with an IgM molecule (IgM monoclonal immunoglobulin) creating a class II cryoglobulinaemia.

It is to be mentioned that in the cryoprecipitate of plasma cryoglobulins one can identify complement fractions. At the same time, IgM can act as rheumatoid factor. When both IgG and the IgM it binds to are polyclonal, the cryoglobulins are defined as class III cryoglobulins.

Cryoglobulins can deposit at the level of the vascular endothelium where they produce vasculitis with cutaneous manifestations and with other localizations as well. Sometimes this vasculitis is severe.

There are situations in which cryoglobulins are present in the circulation without being simultaneously accompanied by the HCV antigen. They are defined as essential cryoglobulins.

$\mathrm{HCV}$ proteins could cause expansion of $B$ cells that will release IgM with rheumatoid-factorlike character (Charter and Dustin) [14].

One mechanism by which glomerular injury is produced during HCV hepatitis is related to the deposition of immune complexes.

A role in the deposition of immune complexes is played by Toll-like receptors, such as TLR-3, which they can activate, accompanied by production of TNF alpha, cytokines and chemokines.

The increased expression of TLR-3 is also accompanied by the presence of mononuclear cells in glomerular diseases associated with HCV [15].

Non-immune mechanisms could also participate. They could involve insulin-like growth factor-1 and TGF-beta.

The deposition of immune complexes could lead to mesangial proliferation. An up-regulation of the expression of angiotensin II type-1 receptors would intervene at the level of mesangial cells, which could determine increased oxidative activity.

The proliferation of mesangial cells causes their migration to the level of the sub-endothelial area, leading to thickening of the area of the basal membrane. Membranoproliferative glomerulonephritis occurs. 
It is to be mentioned that vasculitis related to cryoglobulins present in HCV hepatitis also impairs the glomerular endothelium.

In HCV infection one can notice autoantibody reactivity. Tana and Heller et al. showed that in HCV hepatitis one can notice the presence of autoantibodies with development of autoimmune phenomena [16]. The self antigens against which the autoantibodies are directed play an important role. At the same time, it is found that an important part is also played by molecular mimicry of self antigens with viral antigens which could have an important role in the production of autoantibodies by B cells [17].

Marceau et al. mentioned as candidates for molecular mimicry $\mathrm{HCV}$ core proteins E2, NS 3 and NS 5a. They noticed cross-reactivity at B cell level between cytochrome P450 2D6 (CYP2D6) and $\mathrm{HCV}$, NS 3, NS 5a. Anti-kidney microsome type 1 (LKM1) autoantibodies also have affinity to CYPD6 and can be present in patients with HCV hepatitis [18].

An element that has to be taken into account is the fact that chronic liver disease alters the liver clearance capacity of immune complexes by resident cells equipped with such properties as Kupffer cells.

It is to be noted that the kidney and the liver operate as a real binomial, which, during pathologic processes, acquires new valences that will be reflected in the pathology of hepatic involvement and in renal pathology during hepatitis $C$ [19].

\section{DEPOSITS OF IMMUNOGLOBULINS AND HCV ANTIGENS}

The relationship between $\mathrm{HCV}$ antigens and/or anti-HCV antibodies and the kidneys can be certified by their presence at kidney level.

Immunofluorescence studies on renal biopsies showed in membranoproliferative glomerulonephritis deposits of Ig, mainly IgG and IgM, as well as of complement, especially $\mathrm{C} 3$. The deposits document the accumulation of immune complexes.

The deposits have a granular aspect, and they are located mesangially and along the glomerular capillaries. Electron microscopy locates them subendothelially [20]. Deposits of immunoglobulins at the level of small vessels were found in some patients, corresponding to vasculitis.

Deposits of cryoglobulins at glomerular capillary level take the form of eosinophilic thrombi. In electron microscopy the deposits corresponding to cryoglobulins are micro-tubular or annular- shaped [21].
The deposits of HCV antigens are another evidence of the possible intervention of immune processes as such, or under cryoglobulin form.

Sansanno et al. found that in membranoproliferative glomerulonephritis with cryoglobulinemia deposits of HCV proteins are arranged subendothelially along capillary walls. Concomitantly, deposits of IgG, IgM and C3 which, in electron microscopy have the same localization, have been identified [22].

In membranoproliferative glomerulonephritis of positive HCV-RNA patients, Cao et al. found granular and linear deposits of HCV-NS 3 antigen located both mesangially and along glomerular capillaries (Cao et al.) [23].

Deposits of viral antigens were found by Kong et al. in the kidney in patients with HCV hepatitis, under conditions of their absence in serum [24].

From the histopathological point of view the main manifestation is membranoproliferative glomerulonephritis accompanied or not by cryoglobulinaemia. Another form of manifestation of $\mathrm{HCV}$ hepatitis can be mesangial proliferative glomerulonephritis. It is associated with deposits of $\operatorname{IgA}$ producing IgA nephropathy.

Rare forms are: membranous nephropathy, fibrillar glomerulonephritis, and focal and segmental glomerulosclerosis.

Other forms of manifestation are very rare: periarteritis nodosa, which can also appear as mixed cryoglobulinaemia syndrome.

Sometimes histopathological forms can be associated with extra-capillary proliferation producing crescentic glomerulonephritis.

Periarteritis associated with HCV hepatitis, unlike nephropathy associated with HBV, is found much more rarely than the one associated with HBV hepatitis.

\section{TREATMENT}

Treatment of HCV hepatitis associated glomerulonephritis is based on antiviral therapy which, by diminishing the reserves of virus can also reduce the quantity of immune complexes.

Classical therapy is pegylated interferon associated with ribavirin.

Treatment of $\mathrm{HCV}$ is being continuously developed. New medicines have entered the clinical arena being recommended depending on the genotype of the virus such as: telaprevir, boceprevir, simeprevir, sofosbuvir, etc. (WHO-2014) [25]. Ledipasvir is another antiviral drug. 
Johnson et al. found in membranoproliferative glomerulonephritis good results with pegylated interferon with diminution of proteinuria. Favorable results were also obtained in membranoproliferative glomerulonephritis with pegylated interferon associated with ribavirin [26].

Therapy with rituximab, a monoclonal antibody to the CD 20 antigen of $\mathrm{B}$ cells, seems to diminish the production of cryoglobulins.

The results in patients with $\mathrm{HCV}$ associated mixed cryoglobulinaemia were accompanied by improvement of renal function [27].

Infection with HCV in glomerulonephritis is accompanied by inflammatory phenomena. The progressive evolution sometimes requires the use of steroids and cyclophosphamide. As these medications can facilitate viral replication they are associated with antiviral medication and with monitoring of HCV-RNA.

Lately, the use of mophetil mycophenolate has been discussed which would not increase viral replication.

Prophylactic immune treatment, by vaccination against $\mathrm{HCV}$, is confronted with the great variability of $\mathrm{HCV}$ and is not applied in current practice.

\section{HCV-RELATED RENAL DISEASE AND RENAL TRANSPLANTATION}

In HCV positive patients who have undergone kidney transplantation, de novo glomerulopathy has been found.

We mention membranoproliferative glomerulonephritis, membranous nephropathy, minimal change disease, thrombotic microangiopathy, acute transplant glomerulopathy and chronic transplant glomerulopathy [28].

The most frequent is membranoproliferative glomerulonephritis, sometimes accompanied by cryoglobulinaemia [28].

\section{NON-ALCOHOLIC FATTY LIVER DISEASE IN RELATION TO CHRONIC KIDNEY DISEASE}

Non-alcoholic fatty liver disease (NAFLD) is considered one of the main chronic liver diseases. It is estimated to affect between $20-30 \%$ of the Japanese population. From these persons, 10\% would have a progressive evolution towards nonalcoholic steatohepatitis (NASH) [29]. The disease is also widespread in Western countries. It is considered a public health problem at present.
NAFLD is associated with some metabolic diseases: the metabolic syndrome, diabetes mellitus type 1 and 2, obesity and dyslipidemias. NAFLD is also associated with insulin resistance.

\section{THE NAFLD-CKD RELATION}

NAFLD is associated both with the prevalence and with the incidence of CKD.

This association might be based on pathogenic mechanisms that concomitantly affect the liver and the kidneys. NAFLD is considered to be a risk factor for CKD. In its turn, CKD represents a risk factor for CLD.

NAFLD diagnosed by ultrasound is often associated with CKD in Koreans aged 50 or older [30].

The 1988-1994 NHANES study, based on ultrasound-diagnosed NAFLD does not find an association with prevalent CKD among adults after correction for the presence of elements of metabolic syndrome [31].

It is important to note that populational studies bring arguments in favor of an NAFLDCKD association.

An analysis of data in the literature performed by Targer et al. pointed to the association of NAFLD with CKD, regardless of an association with high blood pressure and obesity. This frequent association was found in patients with or without diabetes [32].

A meta-analysis conducted by Musso et al. on 63902 cases of NAFLD found a relation between the severity of NAFLD which increased with the severity of CKD [33].

An association of NAFLD with CKD and diabetes mellitus Type 1 is present, without being related to other risk factors [32]. Moreover, Bulum and Duvnjak consider that NAFLD would be a factor involved in the development and progression of CKD in patients with DM type 1 [34]. A relation between NAFLD and CKD can also be found in diabetes mellitus type 2 [32].

Studies based on biopsies which confirmed NAFLD in the NASH stage found that those cases presented more frequently than controls microalbuminuria [35].

\section{PATHOPHYSIOLOGY}

In NAFLD an accumulation of free fatty acids occurs at the level of the hepatocytes that 
leads to hepatic steatosis. They cause toxicity at hepatocyte level. It is manifested by elimination of reactive oxygen species (ROS). At the same time an increased quantity of inflammatory cytokines such as IL6 and TNF-alpha is secreted. Stellate cells also secrete an inflammatory mediator called resistin.

As a consequence, other cells such as Kupffer cells, dendritic cells, B cells, NK, NKT, and monocytes- are involved too, being capable of operating in hepatic inflammatory processes in NAFLD.

Mature adipose cells produce adipokines that neutralize inflammatory cytokines.

Kupffer cells participate in the oxidative stress of hepatocytes via ROS. Kupffer cell dysfunction with impaired phagocytosis produces impaired clearance of lipopolysaccharides aggravating liver injury.

Anti-malonyl antibodies also play a role being incriminated in lipid peroxidation.

According to Adhikari and Oren inflamematory cytokines produce phosphorylation and inactivation of adenosyl mono-phosphatase-kinase (AMPK). As a consequence, synthesis of fatty acids at liver level increases.

At the same time, it is generally known that AMPK is present at podocyte level, operating as an energetic sensor with activity related to adiponectin. Diminished synthesis of adiponectin could facilitate the action of cytokines with inflammatory role [36].

Hepatocytes also secrete anti-inflammatory protective factors.

Ix and Sharma consider that adiponectin has a role in the cross-talk beetwen adipose tissue, kidney and liver. They report that liver-secreted protein fetuin-A inhibits generation of adiponectin in adipose tissue. Ix and Sharma consider that adiponectin and fetuin-A have a key role in orchestrating this cross-talk [37].

Muralidane et al., in their experimental studies on mice, found an increase in pro-fibrinogenic markers and fibrosis in the liver concomitantly with hepatic inflammatory processes. These could be related to innate immunity alterations [38].

It has been demonstrated that intestinal bacteria via endotoxins they produce have a role in hepatic inflammatory processes when the liver is injured. A migration of pathogenic germs to the adjoining intestinal lymph nodes - as well as to other organs - can also occur [39]. At this level they activate via Toll-like receptors the immune system which participates in inflammation at hepatic level, a mechanism involved in NAFLD production and evolution.
Probiotics are considered to have positive effects [40].

According to Orlic et al., the renin angiotensin system is a possible factor that establishes a relationship between NAFLD, microalbuminuria and renal failure, being involved in hepatic fibrogenesis and in the impairment of renal function [41].

The kidney-liver cross-talk operates also vice-versa. The kidney-liver relation is influenced during CKD. Thus, during CKD, there occurs a perturbation of the clearance of triglycerides-rich proteins related to a limited activity of lipoprotein lipase and of the LDL receptor located in the liver [42]. As a consequence a real vicious circle ensues.

NAFLD can progress from steatosis to steatohepatitis, which, in its turn, can progress towards cirrhosis and even liver cancer.

Treatment entails limited intake of fructose, Vit E, Omega-3 fatty acids and probiotics (Yang et al.) [43].

\section{IGA NEPHROPATHY AND ALCOHOLIC CIRRHOSIS}

Alcoholic cirrhosis can be associated with renal involvement. This can be manifested either acutely, as hepato-renal syndrome, or chronically, as CKD. Alcoholic cirrhosis is known to be associated with IgA nephropathy.

Since alcoholism affects many people, and as it often progresses to chronic liver disease and ensuing cirrhosis, thorough knowledge about renal impairment has to be considered.

IgA nephropathy in alcoholic chronic liver disease occurs as a result of circulating immune complexes (CIC) containing IgA.

Two processes contribute to high levels of IgA:

- an increased production of $\operatorname{Ig} \mathrm{A}$

- diminished clearance of IgA.

Normally, in the circulation there are two types of $\operatorname{IgA}$ : monomeric IgA, representing $90 \%$ of the total IgA and polymeric IgA. The main form of $\operatorname{IgA}$ with pathogenic role is $\operatorname{Ig} \mathrm{A}_{1}, \operatorname{Ig} \mathrm{A}_{2}$ being more limited. Polymeric IgA originates in the bowel which during liver cirrhosis presents permeability disorders that allow polymeric $\operatorname{IgA}$ in the bowel to enter the blood flow.

$\mathrm{T}$ cells secrete lymphokines which stimulate $\mathrm{B}$ cells to produce IgA, the main part being played by interleukin 6 . As a consequence, immune responses are amplified. 
Clearance of circulating immune complexes is performed by Kupffer cells. These present Fc receptors for IgA which play an important role in removing mainly polymeric IgA.

Monomeric IgA can also be removed by hepatocytes.

Monocytes could participate in IgA clearance. They have $\mathrm{Fc}$ receptors for IgA. One of their functional deficiencies is related to the clearance of immune complexes containing IgA [44].

At the same time, because of functional impairment in liver cirrhosis, the clearance of immune complexes is disturbed and the values of $\operatorname{IgA}$, especially polymeric $\operatorname{IgA}$ in the serum, increase [45].

The increase of IgA in the circulation is followed by their deposition at kidney level. Moreover, in alcoholic cirrhosis one can find abnormalities in the glycosylation of Ig $\mathrm{A}_{1}$, which could cause IgA nephropathy.

According to Tissandie et al., the abnormality could affect polymeric IgA ${ }_{1}$ in the serum of the patients. Modified $\operatorname{IgA}_{1}$ could form immune complexes containing IgG, IgA 1 and $\mathrm{CD}_{81}$ [46]. These could reflect special properties of the immune complexes present in patients with alcoholic cirrhosis, different from those in primary IgA nephropathy. level.

IgA deposits occur predominantly at mesangial
It should be noted that, unlike idiopathic IgA nephropathy, in which circulating immune complexes induce an important proliferation, the immune complexes in IgA nephropathy in liver cirrhosis are not accompanied by marked proliferation.

Because of these characteristics, the renal manifestations in liver cirrhosis are clinically less important. They can appear as haematuria, and/or proteinuria, and totally exceptionally they can present as nephrotic syndrome [47] and mild renal impairment.

These particularities of IgA nephropathy in liver cirrhosis indicate a special liver-kidney relation.

IgA nephropathy in alcoholic cirrhosis is sparsely discussed. It requires attentive study, especially since alcoholic cirrhosis can be associated with $\mathrm{B}$ and $\mathrm{C}$ viral infections causing glomerular disease, including IgA nephropathy. The involved immune mechanisms might be more clearly expressed in this case.

\section{CONCLUSIONS}

The kidney-liver and CKD-CLD relation is complex. Immune mechanisms are one of the most important factors contributing to this inter-connection.

This kidney-liver binomial has to be also analyzed from an immune viewpoint, as immune mechanisms can cause the - sometimes important participation of the kidney in liver diseases.

Relația dintre Boala Cronică de Rinichi $(B C R)$ şi alte organe se remarcă prin complexitatea sa. Cea mai cunoscută şi de altfel cea mai importantă este cea cu aparatul cardiovascular. Mai puțin cunoscute sunt relațiile cu alte organe, deşi implicarea lor uneori domină tabloul clinic şi evoluția bolii.

Lucrarea analizează relația dintre rinichi şi ficat, respectiv dintre boala cronică de rinichi şi cea de ficat. Ea se adresează acesteia prin prisma relațiilor imune dintre cele 2 organe în raport cu patologia lor.

Sistemul imun funcționeaza ca un tot unitar. Există o inter-dependență între sistemul imun al ficatului, considerat un organ limfoid şi rinichi, a cărui participare în procesele imune este bine cunoscută.

Principalele boli hepatice cronice sunt hepatitele virale $B$ şi $C$. Infecția cu aceste virusuri poate duce la o afectare renală, în principal glomerulară.

În acelaşi timp, glomerulonefrita cronică secundară poate determina o evoluție nefavorabilă a bolii.

Relația dintre boala cronică de ficat și cea renală din cursul hepatitelor cronice $B$ şi $C$ se realizează prin intermediul complexelor imune circulante sau formate in situ. Participă şi mecanismele imunitpții celulare, în care un rol principal revine limfocitelor $T$.

Tratamentul antiviral al afecțiunii hepatice se adresează în acelaşi timp şi glomerulonefritelor secundare. 
Participarea mecanismelor imune aduce în discuție în anumite cazuri aplicarea medicației imunomodulante, medicație care poate condiționa replicarea virală, motiv pentru care se asociază cu cea antivirală.

Alte două boli hepatice cronice în relație cu importante boli metabolice, respectiv ciroza hepatică, în care mecanismul principal este cel toxic şi Nonalcoholic steatosic hepatitis vor determina prin mecanisme imune, respectiv prin intermediul complexelor immune, o afectare glomerulară.

Corresponding author: Prof. dr. Gheorghe Gluhovschi 300088 Timoşoara, Calea Aradului No. 8, Ap. 16

E-mail: ggluhovschi@yahoo.com

\section{REFERENCES}

1. BALMASOVA IP, YUSHCHUK ND, MINBAEV OA, ALlA NR, MALOVA ES, ZHONG JE, SHI Z, GAO CI. Immunopathogenesis of chronic hepatitis. World J. Gastroenterol. 2014, 20, 39, 14156-14171.

2. TREPOC CHAN HL, LOK A. Hepatitis B virus infection. Lancet. 2014, 384, 9959, 2053-2063.

3. LIU XR, SHEN YH. Membranous glomerulopathy associated with hepatitis B virus infection. HKig Pediatr (newseries), 2002, $13,22-29$.

4. VENKATASESHAN VS, LIEBERMAN K, KIM DU, THUNG S, DIUMAN S. Hepatitis B associated glomerulonephritis: pathology, pathogenesis and clinical course. Medicine (Baltimore) 1990, 69, 4, 200-216.

5. ZHANG JH, LI ZHOU N. Is there a hepatitis B virus-assocated glomerulonephritis? Identification of HBsAg, $H B c$ and $H B c A g$ with monoclonal antibodies. Chin. Med. J. (Engl)1989, 108, 7, 496-504.

6. LIN CY, LIN CS, CHANG GH. Defect of cell mediated immune response against hepatitis; an indication for pathogenesis of hepatitis B virus-associated membranous nephropathy. Nephron $1994,765,176-185$.

7. PENG G, Li S, WU W, SUN Z, CHEN Y, CHEN Z. Circulating CD4+CD25+ regulatory T cells correlate with chronic hepatitis $B$ infection. Immunology. 2008, 123, 57-65.

8. LU H, ZHU H, ZHOU Y. S gene mutation of HBV in children with HBV-associated glomerulonephritis. Virol. J. 2012, 9, 59, doi 10.IV 86/1743/422Y-9-5.

9. HUI D, YAN V, WEI Y, RUIXIZ M, GUANGIU G. Significance of mutations in hepatitis B virus $X$ gene for pathogenesis HBV-associated glomerulonephritis. Acta Virol. 2014, 58, 3, 278-281.

10. LAI KH, HO RT, TAM JS, LAI FM. Detection of hepatitis B virus DNA and RNA in kidney of HBV related glomerulonephritis. Kidney Int. 1996, 50, 6, 1965-1997.

11. El-SERAQ HR, HAMPEL H, YEH E. RABENECK I. Extrahepatic manifestations of hepatitis C among United States male veterans. Hepatology 2002, 36, 6, 1439-1445.

12. MOE SM, PAMPALONE A, OFNER S, ROSEMAN M, TED E, HUI SL. Association of hepatitis $C$ virus infection with prevalence and development of kidney diseases. Am J. Kidney Dis 2008, 51, 6, 885-892.

13. FABRIZI F, MARTIN P, DIXIT V, MESSA P. Hepatitis virus infection and kidney disease: a meta analysis. Clin J. Am Soc Nephrol. 2012, 7, 4, 549-557.

14. CHARTER Ed, DUSTIN LB. Hepatitis C virus-induced cryoglobulinaemia. Kidney Int 2009, 76, 8, 818-824.

15. FABRIZI F, MESSA P, MARTIN P. Novel evidence on hepatitis C virus-associated glomerular disease. Kidney Int. 2014, 86, 3, 466-469.

16. TANA MM, HELLER T. Autoantibodies in hepatitis C: red flag or bystander. J Pediat Gastroenterol. Nutr. 2013, 56, 3, 243.

17. FERRY S, MURATORI L, LENZI M. HCV and auto immunity. Curr. Pharm. Dis 2008, 14, 1672-1685 (Pub Med).

18. MARCEAU G, LAPIERRE P, BELAND K, SAUDEYENS H, ALVAREZ F. LKM and autoantibodies in chronic hepatitis $C$ infections. A case of molecular mimicry? Hepatology 2005, 42, 675-682.

19. STOKES MB. Immune complex glomerulonephritis in patients with hepatitis C. Saudi J Kidney Dis Transpl (Serial Online). 2000, 11, 3, 396-404.

20. HO V, CHEN J. Hepatitis XC virus associated glomerulonephritis in: PRZONACAR S, An update on glomerulonephritis. Clinical and treatment aspects. 2011. In tech Shanghai, China.

21. ISKANDAR SS, HERRERA GA. Glomerulopathies with organized deposits. Semin Diagn Pathol 2002, 19, 3, 116-132.

22. SANSANNO D, LAULETTA G, MONTRONE M, GRANDALIANO G, SCHENA FP, DAMMACCO F. Hepatitis $C$ virus $R N A$ and core protein in kidney glomerular and tubular structures isolated with laser capture microdissection. Clin Exp Immunol 2005, 140, 3, 498-506.

23. CAO Y, ZHANG Y, WANG S, ZOU W. Detection of the hepatitis $C$ virus antigen in kidney tissue from infected patients with various glomerulonephritis. Nephrol Dial Transplant. 2009; 24, 9, 2745-2751.

24. KONG D, WU D, VAN T, LI T, ZU S, CHEN F, KIN X, LOU C. Detection of viral antigens in renal tissue of glomerulonephritis patients without serological evidence of hepatitis $B$ virus and hepatitis $C$ virus infection. Int. J. Infect Dis 2013, 17, 7, e 535-e538.

25. WHO. Hepatitis C. Fact sheet update. April 2014. 
26. JOHNSON RJ, GRETCH DR, COUSER WG, ALPERS CE, WILSON J, CHUNG N et al. Membranoproliferative glomerulonephritis associated with hepatitis C virus infection. N Engl. J. Med 1993, 328, 7, 465-470.

27. QUARTUCCIO L, SOARDO GE, ROMANO G, SCOTT CA, De MARCHE G et al. Rituximab treatment for glomerulonephritis in $\mathrm{HCV}$-associated mixed cryoglobulinaemia; efficacy and safety in the absence of steroids. Rheumatology, 2006, 45, 7, 842-846.

28. HO V, CHEN J. Hepatitis C virus associated glomerulonephritis in: PRABHAKAR SEd. An update on glomerulopathies. Clinical and treatment aspects 2011. In: Tech Shanghai, China.

29. SUGIMOTO K, TAKEI. Clinicopathological features of non-alcoholic fatty liver disease. Hepatol Res 2011, 10, 911-920.

30. AHN AL, CHOI JK, KIM MN, KIM SA, OH EJ, KUCON HJ, CHO DY. Non-alcoholic fatty liver disease and chronic liver disease in Koreans aged 50 years or older. Korean J. Fam Med. 2013, 34, 3, 199-205.

31. SIROTA JC, McFANN K, TARGHER G, CHONCHOL M, JALAL DI. Association between nonalcoholic liver disease and chronic kidney disease: an ultrasound analysis from NHANES 1988-1994. Am J Nephrol. 2012, 36, 5, 466-71. doi: $10.1159 / 000343885$.

32. TARGER G, CHONCHOL M, ZOPPINI G, ABATERUSSO C, DONORA E. Risk of chronic kidney disease in patients with non-alcholic fatty disease. Is there a link? J Hepatol 2011, 54, 5, 1020-1029.

33. MUSSO G, GAMBINO R, TABIBIAN JH. Association of non-alcoholic fatty liver disease with chronic kidney disease: a systematic review and meta-analysis. Plos Med. 2014, 11, 7: e 1001680 doi 10.1374/journal p med 1001680 e collection 2014.

34. BULUM T, DUVNJAK L. Relationship between nonalcoholic fatty liver disease markers and renal function in patients with type 1 diabetes. Acta Med Croatia 2011, 65, Supp 1, 3, 6-10, Pub Med.

35. YILMAZ Y, ALAHDAB Y, YONAL O. Microalbuminuria in non-diabetic patients with nonalcoholic fatty liver disease associated with liver fibrosis. Metabolism 2010, 59, 9, 1327-1330.

36. ADHIKARI KB, OREN T. Non-alcoholic fatty liver disease (NAFLD) and immune response. J Inst Med 2010, 3, 43-53.

37. IX JH, SHARMA K. Mechanisms linking obesity, chronic kidney disease and fatty liver disease, the role of fetuin A, adiponectin and AMPK. J Am Soc Nephrol 2010, 21, 3, 406-412.

38. MOURALIDANE A, SOEDA J, VISCONTI-PUGMIRE, SAMULELSON A, TOMBO J, MARAGKOUDAKI X. Maternal obesity programs offspring non-alcoholic fatty liver disease via innate immune disjunction in mice. Hepatology 2013, 52, 128-138.

39. AMOR J, CHABO C, WAGET A, KLOPP P, VACHOU C, BEMUDEZ-HUNARAN LG. Intestinal mucosal adherence and translocation of commensal bacteria at the early onset of type 2 diabetes, molecular mechanisms and probiotic treatment. EMBO, Mol Med. 2011, 3, 559-572.

40. MELI R, RASO GM, CALIGNANO A. Role of innate response in non-alcoholic fatty liver disease: metabolic complications and therapeutic tools. Front Immunol 2014/doi: 103389/ fimmu 2014-00177.

41. ORLIC I, MIKOLASEVIC I, BAGIC Z, RACUL S, STIMAC D MILIC. Chronic kidney disease and non-alcoholic liver disease - is there a link? Gastroenterol. Res. Pract. 2014, doi org/10-1155/2014/847539.

42. JIN K, NORIS K, VAZIRI ND. Dysregulation of hepatic fatty acid metabolism in chronic kidney disease. Nephrol Dial Transplant. 2013, 28, 2, 313-320.

43. YANG M, GONG S, YE SQ, LYMAN B, CHEN P, DY L. Non-alcoholic fatty liver disease in children: focus on nutritional interventions. Nutrients 2014, 6, 1, 4691-4705.

44. NEWELL CC. Cirrhotic glomerulonephritis, incidence, morphology, clinical features and pathogenesis. Am. J. Kidney Dis. 1987, 9, 3, 183-190.

45. POURIS S, FEEHALLY J. Glomerular IgA deposition in liver disease. Nephrol Dial Transplant, 199, 14, 10, $2279-2282$.

46. TISSANDIE E, MORELLE W, BERTHELOT L, VRTOVSNIK F, DAUGAS M et al. Both IgA nephropathy and alcoholic cirrhosis feature abnormally glycosylated $\operatorname{Ig} A_{1}$ and soluble $C_{89}$-IgA complexes common mechanisms for distinct disease. Kidney Int 2011, 80, 12, 1352-1363.

47. KALAMBOKIS G, CRISTOU I, STEFANOU D, ARKEUMANI E, TSIANOS EV. Association of liver cirrhosis related IgA nephropathy with portal hypertension. World J Gastroenterol, 2017, 13 13, 43, 5783-5786.

Received January 22, 2015 